\title{
ANALISIS FENOTIPIK DAN GENOTIPIK PADA ABNORMALITAS KLON-KLON KELAPA SAWIT (Elaeis guineensis Jacq.) HASIL KULTUR JARINGAN
}

\author{
ENDANG YUNIASTUTI \\ Staf Pengajăr Fakultas Pertanian UNS
}

\begin{abstract}
Research to analyze phenotype and genotype of oil palm clone developed from tissue culture which showed normal fruits and abnormal fruits through SDS-PAGE protein technique, and RAPD technique. Results indicated that protein with molecular weight of $100 \mathrm{kDa}$ could differentiate genotype with normal fruit and abnormal fruit from all clones observed. Study on DNA through RAPD technique revealed primers which differentiated genotypes (male flowered genotype, normal fruited genotype, and abnormal fruited genotype) within clone and interclonal, i.e. OPC-07, OPN-16, and SC 10-56. Molecular weight of DNA on zymogram bands pattern were different on each clone.
\end{abstract}

Genetic similarity among clones and among genotypes were high, more than $85 \%$ indicated close genetic distance. Dendogram based on matrix of genetic similarity indicated grouping on each genotype.

Key Words : phenotype, genotype, tissue culture

\section{PENDAHULUAN}

Tanaman kelapa sawit (Elaeis guineensis Jacq.) adalah salah satu tanaman penghasil minyak nabati utama. Ditinjau dari nilai ekonomi, kelapa sawit memegang peranan penting meningkatkan pendapatan negara dari sektor perkebunan (Tondok, 1998). Peningkatan permintaan kelapa sawit sejalan dengan meningkatmya kebutuhan hasil olahan kelapa sawit berupa Crude Palm Oil (CPO) dan produk derivat lainnya. Salah satu usaha untuk memenuhi permintaan pasar dunia, Indonesia melakukan peningkatan produksi kelapa sawit dengan jalan pembukaan lahan baru. Menurut catatan dari Direktorat Jendral Bina Produksi Perkebunan (2003) pada tahun 2002 luas areal perkebunan kelapa sawit meningkat menjadi 4,1 juta ha.

Penyediaan bibit kelapa sawit dapat dilakukan dengan dua cara, yaitu secara generatif dan secara vegetatif. Perbanyakan generatif menggunakan benih dari biji hasil persilangan Dura dengan Pisifera. (Lubis, 1992). Perbanyakan secara vegetatif, salah satunya dilakukan dengan teknik kultur jaringan. Salah satu keunggulan teknik kultur jaringan adalah mampu menghasilkan bibit dalam jumlah yang banyak dan dalam waktu yang relatif singkat. (Ginting $e t$ al., 1991).

Duran-Gasselin et al. (1993) menyatakan bahwa kelapa sawit hasil kultur jaringan meningkatkan produksi minyak sawit mentah (MSM) sekitar $12 \%$ sampai $30 \%$ dibandingkan dengan tanaman yang berasal dari benih hibrida. Namun, dalam perkembangan beberapa tahun terakhir, ternyata tanaman kelapa sawit hasil Analisis Fenotipik dan Genotipik kultur jaringan yang ada di lapangan menunjukkan gejala abnormalitas yang dijumpai pada organ generatif, yaitu pada bunga dan buah seperti yang dilaporkan pada Konferensi Kultur Jaringan Kelapa Sawit di Kuala Lumpur pada bulan Maret 1986.

Beberapa pendapat menyatakan bahwa mekanisme munculnya abnormalitas berbedabeda untuk setiap genotip dan klon tanaman kelapa sawit. Untuk itu, perlu dilakukan pengamatan fenotipik dan pengamatan genotipik. Pengamatan fenotipik dapat dilakukan dengan analisis protein sebagai salah satu cara karena protein merupakan produk dari gen yang terekspresi secara langsung pada masing-masing bagian tanaman dan pada setiap fase pertumbuhan dan perkembangan tanaman. Pengamatan genotipik pada tingkat DNA karena DNA pada suatu tanaman tidak berubah dan tidak dipengaruhi oleh umur tanaman atau faktor lingkungan sehingga sama pada setiap fase atau tahap pertumbuhan dan perkembangan tanaman. Analisis pada tingkat DNA dapat digunakan untuk deteksi sedini mungkin pada fase pembibitan atau bahkan saat perbanyakan dalam kultur jaringan, khususnya tanaman perkebunan seperti tanaman kelapa sawit. Dengan demikian program pemuliaan tanaman dalam melakukan seleksi akan dipercepat, sehingga dapat memberi rekomendasi lebih awal.

\section{METODE PENELITIAN}

Bahan tanaman kelapa sawit yang digunakan dalam penelitian merupakan koleksi kebun percobaan Badan Pengkajian dan 
Penerapan Teknologi (BPPT) di Ciampea yang berumur lima tahun. Pada penelitian dilakukan dua kegiatan penelitian, yaitu: (1) analisis protein dengan SDS-PAGE Protein; (2) analisis DNA dengan RAPD.

Bagian tanaman yang digunakan dalam analisis protein dengan SDS-PAGE Protein adalah bagian bunga jantan, buah normal, dan buah abnormal. Analisis protein dengan SDSPAGE Protein dilakukan pada dua tahap percobaan, yaitu tahap satu, untuk melihat pola pita protein pada genotip yang berbeda dalam satu klon, dilakukan pada klon MK 152 untuk semua genotip, yaitu berbunga jantan, berbuah normal, dan berbuah abnormal, dan masingmasing genotip dilakukan pada dua tanaman (jantan-1, jantan-2, normal-1, normal-2, abnormal-1, abnormal-2). Tahap dua dilakukan untuk melihat pola pita protein pada masingmasing genotip antara klon yang satu dengan klon yang lain. Tahap dua dilakukan pada enam klon, yaitu MK 104, MK 152, MK 176, MK 203, MK 209, dan MK 212 yang masing-masing klon terdiri atas genotip berbuah normal, dan berbuah abnormal sehingga jumlah yang dianalisis adalah $6 \times 2=12$ genotip.

Untuk analisis DNA dengan RAPD, tanaman kelapa sawit yang digunakan adalah tiga klon kelapa sawit hasil kultur jaringan yaitu MK 152, MK 209, dan MK 212. Bagian tanaman yang diambil dalam analisis DNA dengan RAPD adalah daun yang masih muda (daun tombak) dari klon kelapa sawit yang berbunga jantan, berbuah normal, dan berbuah abnormal (mantel berat).

Analisis data yang diperoleh dari hasil elektroforesis pada SDS-PAGE Protein, dan RAPD berdasarkan penampilan pola pita protein dan pola pita DNA menggunakan analisis gerombol (cluster analysis) dengan teknik berhierarki yang ada dalam program Numerical Taxonomy and Multivariate Analysis System versi 2.10 (NTSYS) metode Sequential, Agglomerative, Hierarchical, and Nested Clustering (SAHN) (Rohlf, 1993). Selanjutnya pengelompokan itu ditampilkan dalam bentuk dendogram (Franco et al., 1997). Ukuran derajat jarak kemiripan genetik antara klon berdasarkan koefisien kemiripan (similarity coefficient) atau jarak genetik (genetic distance) dengan menggunakan metode Group Average Clustering yang ada dalam program NTSYS dipilih metode Unweight PairGroup Method Arithmetic (UPGMA) dengan rumus sebagai berikut :

$$
\mathrm{d}_{(\mathrm{ij}) \mathrm{k}}=\frac{\sum \sum \mathrm{n}_{\mathrm{ij}} \mathrm{n}_{\mathrm{k}}}{\mathrm{n}_{(\mathrm{ij})} \mathrm{n}_{\mathrm{k}}}
$$

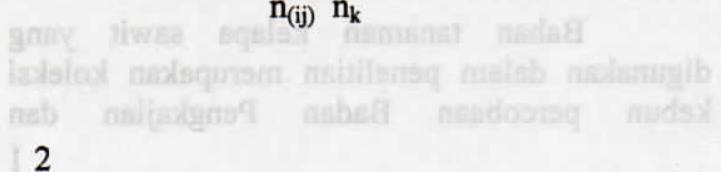

Keterangan :

$\mathrm{d}_{(\mathrm{ij}) \mathrm{k}}=$ ukuran ketidakmiripan antara gerombol ke$\mathrm{k}$ dengan gerombol ij yang merupakan penggabungan ke-i dan ke-j

$\mathrm{d}_{\mathrm{st}}=$ ukuran ketidakmiripan antara gerombol ke$s$ dalam gerombol ij dan gerombol ke-t dalam gerombol $\mathrm{k}$

$\mathrm{n}_{(\mathrm{ij})}=$ jumlah anggota $\mathrm{i}$ dalam gerombol $\mathrm{ij}$

$\mathrm{n}_{\mathrm{k}}=$ jumlah anggota gerombol $\mathrm{k}$

Fragmen yang dihasilkan pada analisis SDS-PAGE, dan RAPD yang tampak sebagai pita-pita protein dan DNA diterjemahkan menjadi data biner berdasarkan ada atau tidaknya pita yang dimiliki secara bersama oleh individu tanaman yang dianalisis. Pita protein memiliki ukuran berat molekul $(\mathrm{kDa})$ tertentu dan pita DNA memiliki ukuran pasangan basa (bp) tertentu. Setiap pita dianggap sebagai satu lokus sehingga pita yang sama dari contoh tanaman dinterpretasikan sebagai satu lokus yang homolog. Lokus tersebut diubah ke dalam bentuk data biner dengan memberi nilai satu (1) untuk yang memiliki pita dan nilai nol (0) untuk yang tidak memiliki pita.

Estimasi kemiripan genetik diperoleh berdasarkan jumlah pita yang dimiliki bersama. Pengelompokan data matrik dan pembuatan dendogram dilakukan dengan metode UPGMA, fungsi Similarity Qualitative (SIMQUAL) pada program NTSYS versi 2.1 (Rohlf, 1993). Tingkat kepercayaan dari dendogram berdasar UPGMA ditentukan melalui analisis bootstrap menggunakan program Winboot dengan pengulangan (Yap dan Nelson, 1996). Data matrik kemiripan genetik dihitung dengan rumus dari kofisien Dice (S) (Nei (1987) yaitu:

$$
\mathrm{S}=2 \mathrm{n}_{\mathrm{ab}} /\left(\mathrm{n}_{\mathrm{a}}+\mathrm{n}_{\mathrm{b}}\right)
$$

Keterangan: $\mathrm{S}=$ Koefisien kemiripan; $\mathrm{a}$ dan $\mathrm{b}=$ individu tanaman; $\mathrm{n}_{\mathrm{ab}}=$ jumlah pita yang posisinya sama; $n_{\mathrm{a}}=$ jumlah pita individu tanaman $a ; n_{b}=$ jumlah pita individu tanaman $b$

Dari analisis klaster dengan metode UPGMA diperoleh dendogram. Untuk meningkatkan akurasi hasil, dilakukan analisis bootstrap dengan ulangan 2000 kali. Dengan demikian, diperoleh angka-angka yang merupakan persentase tingkat ketelitian. Angkaangka pada garpu dendogram hasil analisis bootstrap pada dasarnya menunjukkan tingkat kepercayaan pengelompokan dendogram berdasarkan koefisien kemiripan genetik.

Jika jarak genetik antar genotip cukup dekat dilihat dari koefisien genetik yang tinggi, dilanjutkan Analisis Komponen Utama (AKU) 
untuk mendapatkan nilai skor yang dapat digunakan untuk melihat posisi relatif setiap genotip berdasarkan tiga komponen utama pertama yang memiliki proporsi varians yang terbesar. Untuk menentukan pita protein atau pita DNA yang paling berperan dalam pengelompokan klon-klon "kelapa sawit - yang normal dan abnormal, matriks tersebut dianalisis lebih lanjut berdasarkan Principal Component (Komponan Utama atau dikenal dengan istilah Analisis Komponen Utama/ AKU) yang diturunkan dari matrik varian-kovarian.

Komponen Utama didefinisikan sebagai kombinasi linear terbobot dari variable asal yang dinyatakan dalam bentuk persamaan matriks yaitu: $Y_{i j}=a_{1 i} X_{i}+a_{2 i} X_{2}+\ldots+a_{p i} X_{p}=a^{\prime}{ }_{i} x$. Vektor pembobot $a_{1}{ }_{1}$ adalah vektor normal serta $\mathrm{a}^{\prime}{ }_{1} \mathrm{a}_{1}=1$ dipilih agar keragaman Komponen utama menjadi maksimum. Matrik kovarians menggunakan rumus sebagai berikut:

$$
\mathrm{S}=\frac{1}{-\sum_{(n-1)} \sum_{h=1}\left(x_{h}-x\right)}\left(x_{h}-x\right)
$$

Keterangan : $\mathrm{n}=$ ukuran sampel $; \mathrm{x}_{\mathrm{h}}=$ obyek pengamatan ke-h

Pita-pita yang berperan untuk membedakan klon kelapa sawit yang normal dan yang abnormal ditentukan dengan mencari pita yang spesifik yang memiliki korelasi yang besar di antara setiap pita (peubah ke-i) dengan komponen utamanya yang ke-j dengan menggunakan rumus Dillon dan Goldstein (1984) sebagai berikut : $\quad r_{i j}=a_{i j} \sqrt{ } \lambda j s_{i}^{-1}$

Keterangan: $\mathrm{a}_{\mathrm{ij}}=$ unsur ke-i dari vector ke-j

$$
\begin{aligned}
& \lambda_{\mathrm{j}}=\text { akar ciri ke-j } \\
& \mathrm{s}_{\mathrm{i}}^{-1}=\text { simpangan baku variable } \mathrm{x}_{\mathrm{i}}
\end{aligned}
$$

Secara skematik, alir analisis data dari pita protein dan pita DNA yang dihasilkan dalam penelitian mulai transformasi pita ke dalam data biner sampai penampilan data dalam bentuk pengelompokan dendogram menggunakan metode UPGMA.

\section{HASIL DAN PEMBAHASAN}

\section{Analisis Pola Pita SDS-PAGE Protein Klon Kelapa Sawit MK 152}

Dari hasil yang diperoleh ada perbedaan pita protein antar genotip dalam klon MK 152 pada BM $25 \mathrm{kDa}-45 \mathrm{kDa}$. Genotip jantan $\left(\hat{\sigma}_{1}\right.$ dan $\hat{\delta}_{2}$ ) memiliki pita protein dengan BM $25 \mathrm{kDa}$ dan $27 \mathrm{kDa}$, sedangkan genotip abnormal $\left(\mathrm{Ab}_{1}\right.$ dan $\mathrm{Ab}_{2}$ ) memiliki pita protein dengan BM 25 $\mathrm{kDa}, 29 \mathrm{kDa}, 35 \mathrm{kDa}$ dan $45 \mathrm{kDa}$. Genotip normal $\mathrm{N}_{1}$ dan $\mathrm{N}_{2}$ tidak memiliki pita protein $\mathrm{BM}$ Analisis Fenotipik dan Genotipik
$25 \mathrm{kDa}-27 \mathrm{kDa}$, tetapi memiliki pita protein BM $29 \mathrm{kDa}, 35 \mathrm{kDa}$, dan $45 \mathrm{kDa}$ seperti genotip abnormal. Dari hasil tersebut tampak bahwa genotip jantan dan abnormal terbentuk protein baru dengan BM antara $25 \mathrm{kDa}$.

Pita-pita protein yang dihasilkan dalam analisis SDS-PAGE Protein menghasilkan nilai koefisien kemiripan genetik yang cukup tinggi, yaitu 0.93 sampai 0.98 . Koefisien kemiripan genetik terendah adalah 0.93 , yaitu antara klon MK 152 jantan 1 dengan klon MK 152 Abnormal 1dan Abnormal 2, sedangkan koefisien kemiripan genetik tertinggi adalah 0.98 antara klon MK 152 Abnormal-1 dan Abnormal-2 dengan klon MK 152 Normal-1 dan Normal-2. Nei (1987) menyatakan bahwa nilai koefisien kemiripan genetik merupakan kebalikan dari jarak genetik. Jarak genetik antar klon MK 152 berbunga jantan, berbuah abnormal (mantel berat), dan berbuah normal memiliki jarak genetik yang sangat dekat karena perbedaan dengan genotip normalnya sangat kecil, yaitu $2 \%$ pada abnormal, $3 \%$ pada $\delta_{1}$, dan $5 \%$ pada $\widehat{\sigma}_{2}$.

\section{Analisis Pola Pita SDS-PAGE Protein Beberapa KIon Kelapa Sawit}

Hasil SDS-PAGE protein beberapa klon kelapa sawit menunjukkan bahwa pita protein yang dihasilkan dari buah normal dan berbuah abnormal pada kisaran berat molekul (BM) 15 $\mathrm{kDa}-205 \mathrm{kDa}$. Pola pita protein yang dihasilkan masing-masing klon pada setiap genotip berbuah normal dan berbuah abnormal hampir sama yaitu dari 31 pita protein yang dihasilkan ada 16 pita protein yang sama dimiliki oleh semua genotip pada klon yang diamati, sedangkan 15 pita protein lainnya bersifat polimorfik. Pita protein polimorfik yang dihasilkan dari analisis SDSPAGE protein berada pada kisaran berat molekul $20 \mathrm{kDa}$ sampai $120 \mathrm{kDa}$. Pita protein yang dapat digunakan untuk membedakan klon berbuah normal dan klon berbuah abnormal pada keenam klon yang diamati hanya pada pita protein dengan berat molekul $100 \mathrm{kDa}$. Pita protein dengan berat molekul $100 \mathrm{kDa}$ hanya ditemukan pada klon berbuah abnormal, tidak pada klon berbuah normal. Pita protein polimorfik lainnya pada masing-masing klon menunjukkan pola yang berbeda-beda yang menunjukkan bahwa setiap genotip masing-masing klon menunjukkan respons yang berlainan. Namun demikian, secara garis besar perubahan protein dari klon berbuah normal menjadi klon berbuah abnormal dan perbedaan pola pita protein masing-masing klon terjadi pada protein dengan berat molekul kecil sampai sedang (di bawah BM $150 \mathrm{kDa}$ ).

Besarnya koefisien kemiripan antar 12 genotip dari enam klon kelapa sawit berkisar dari 
0,78 sampai 0,98 Koefisien kemiripan genetik yang terendah adalah 0,78 yaitu antara klon MK212 berbuah normal dengan klon MK152 berbuah abnormal, sedangkan koefisien kemiripan genetik yang tertinggi diperoleh dari klon MK176 berbuah abnormal dengan klòn MK209 berbuah abnormal. Dendogram hasil analisis klaster berdasarkan pola pita protein 12 genotip menunjukkan bahwa pada koefisien kemiripan genetik 0.86 seluruh genotip terbagi menjadi dua kelompok masing-masing genotip berbuah normal dan genotipe berbuah abnormal. Peta posisi relatif setiap genotip memperlihatkan adanya pengelompokan yang sama seperti pengelompokan pada dendogram.

\section{Analisis Polimorfisme DNA dengan Teknik RAPD}

Pola pita DNA yang dihasilkan dari analisis polimorfisme dengan RAPD mempunyai ukuran fragmen berkisar antara 250 bp sampai dengan 2000 bp. Menurut Nienhuis et al. (1994) jumlah pita DNA polimorfis dalam analisis keragaman genetik menentukan tingkat keragaman suatu populasi sehingga banyaknya pita DNA yang polimorfis menggambarkan keadaan genom dari tanaman tersebut. $\mathrm{Di}$ samping itu, Grattapaglia et al. (1992) menyatakan pita DNA polimorfis dapat memperkecil bias yang disebabkan tidak terwakilinya bagian-bagian genom karena pemilihan praimer yang kurang tepat. Perbedaan jumlah dan polimorfisme pita yang dihasilkan oleh setiap praimer menggambarkan kekomplekan genom suatu tanaman. Pita DNA yang dihasilkan berdasarkan 18 praimer RAPD ada 92 pita polimorfik

Dari hasil yang diperoleh tampak bahwa perbedaan antar genotip tanaman yang berbuah normal dan berbuah abnormal dalam satu klon hanya dibedakan oleh satu atau beberapa pita DNA. Pita pembeda tersebut tidak sama untuk masing-masing klon. Hal itu menyebabkan sangat sukar untuk menentukan perbedaan pola pita DNA genotip normal dengan yang tidak normal antar klon yang diuji. Dari keseluruhan hasil analisis DNA dengan RAPD dapat diambil kesimpulan sementara ada tiga praimer yang dapat membedakan genotip jantan, normal dan abnormal yang bersifat konsisten pada semua klon yang diamati, yaitu OPC-07, OPN-16 dan SC 10-56.

Hasil yang diperoleh menunjukkan bahwa pada tingkat koefisien kemiripan genetik sebesar $85 \%$ sembilan genotip dari tiga klon MK terbagi menjadi dua kelompok, yaitu MK152 Abnormal (kelompok I), dan 8 genotip lainnya dalam satu kelompok (kelompok II). Pada tingkat kemiripan genetik $86 \%$ kelompok II terbagi menjadi dua, yaitu MK152 jantan dan tujuh genotip lainnya yang terbagi menjadi dua kelompok pada tingkat kemiripan genetik $87 \%$ yaitu MK 152 normal dengan enam genotip lainnya. Untuk klon MK 209 genotip jantan dan abnormal memiliki kemiripan genetik $97 \%$ yang berarti perbedaan dalam pita DNAnya hanya sekitar 3\%, sedangkan kemiripan genetik jantan dan abnormal dengan normal masing-masing sekitar $6 \%$.

\section{KESIMPULAN}

Dari hasil penelitian yang dilakukan, maka dapat diterik beberapa kesimpulan yaitu:

1. a. Diperoleh pengelompokan berdasarkan genotip pada pengamatan pita protein dari MK 152.

b. Diperoleh protein dengan berat molekul 100 $\mathrm{kDa}$ yang mampu membedakan genotip normal dengan genotip abnormal untuk seluruh klon kelapa sawit yang diamati pada organ generatif.

2. a. Praimer RAPD yang mampu membedakan genotip jantan, normal, dan abnormal pada klon MK 152, MK 209, dan MK 212, yaitu OPC-07, OPN-16, dan SC 10-56.

b. Pola pita DNA polimorfik RAPD berbedabeda untuk masing-masing klon.

3. a. Kemiripan genetic antar klon MK dan antar genotip sangat tinggi yaitu lebih dari $85 \%$, yang berarti jarak genetiknya sangat dekat.

b. Perubahan genotipik yang kecil dapat menimbulkan perubahan fenotipik yang besar.

c. Dendogram menunjukkan bahwa genotip normal berada dalam kelompok yang sama, sedang genotip abnormal (berbunga jantan dan berbuah abnormal) berada dalam kelompok lainnya.

\section{DAFTAR PUSTAKA}

Beer, S.C., J. Goffreda, T.D. Phillips, J.P. Murphy, and M.E. Sorrells. 1993. Assassment of Genetic Variation in Avena sterilis Using Morphological Traits, Isozymes, and RFLPs. Crop Sci. $33: 1386-1393$

Direktorat Bina Produksi Perkebunan. 2003. Produksi, Luas Areal, dan Produktivitas Perkebunan di Indonesia 1998 - 2002 (Online). Available at http://www.bunnas.com (verified 20 Agustus 2003).

Duran-Gasselin, T.Y. Duval, L. Baudouin, A.B. Maheran, K. Konan, and J.M. Noiret. 1993. Description and Degree of the Caraka Tani XXII (1) Maret 2007 
Mantled Flowering Abnormality in Oil Palm (Elaeis guineensis Jacq.) Clones Produced Using the Orstom-CIRAD Procedure. p. 33 - 47. In. V. Rao, I.E. Henson, and Rajanaidu (Ed.). Proc. 1993. ISOPB Int. Symp. Recent Dev. In Oil Palm Tissue Culture and Biothecnology. Kuala Lumpur, 24 - 25 September. 1993.

Ginting, G., R.A. Lubis, dan A.U. Lubis. 1991. Kultur Jaringan Kelapa Sawit (Elaeis guineensis) di Pusat Penelitian Perkebunan Marihat. Seminar Bioteknologi Perkebunan dan Lokakarya Biopolimer PAU-IPB Bogor. p.115 119.

Grattapaglia, D., J. Chaparro, P. Wilcox, S. McCord, D. Werner, H. Emmerson, S. McKlead, F. Bridgewater, R., Whetten, D.O'Malley, and R. Sederoff.1992. Mapping in Woody Plant with RAPD Markers: Application to Breeding in Foresty and Horticulture. p. 37 - 40. In: Aplicatin of RAPD Technology to Plant Breeding. Joint Plant Breeding Symposia Series CSSA/ASHS/AGA, Minneapolis..

International Contact Busines System (ICBS) Inc. 1997. Studi tentang Perkebunan dan Pengawasan Minyak Sawit di Indonesia. ICBS. Jakarta.

JICA. 1996. Manual of Protein and DNA Analysis. National Institute of Agrobiological Resources. Ministry of Agriculture Forestry and Fisheries. Tsukuba. Japan. 57 p.

Jones, L.H. 1991. Endogenous Cytokinins in Oil Palm (Elaeis quineensis L.) Callus, Embryoids and Regerant Plants Measured by Radioimmunoassay. Plant Cell Tissue Organ Cult. 20: $201-210$.

Karp, A. (1995). Somaclonal variation as a tool for crop improvement. Euphytica 85:295-302.
Kemala S., dan Wahyudin. 2000. Peluang Investasi Perbenihan Kelapa Sawit. Pusat Penelitian Sosial Ekonomi. Dirjen Kehutanan dan Perkebunan. Jakarta.

Lubis, A.U. 1992. Kelapa Sawit di Indonesia. Pusat Penelitian Perkebunan Marihat. Bandar Kuala, Sumatra Utara. 435 p.

Nei, M. 1987. Estimation of Average Heterozygosity and Genetic Distance from a Small Number of Individuals: Genet. 89 : $583-590$.

Nienhuis, J., J. Tivang, and P. Skroch. 1994. Analysis of Genetic Reletionship Among Genotypes Based on Molecular Marker data. p. 4-8.In. Analysis Molecular Marker Data. Joint Plant Breeding Symposia Series. Corvalis, Or 5-6 August, 1994. CSSA Am Soc. Hort. Sci. and Am Genet. Assoc.

Rohlf, F.J. 1993. NTSYS-pc. Numerical Taxonomy and Multivariate Analysis System Version 1.80. Exerter Software, New York.

Tondok, A.R. 1998. Production and Marketing of Indonesia Palm Oil: Past, Present and Future. 1998. Int. Oil Palm Conf., Nusa Dua Bali. September $23-25,1998$ Indonesia.

Toruan-Mathius, N., N. Haris, and G. Ginting. 1998. Use of Biomolecular Techniques in Studies of Abnormalities in Oil Palm Clones. Int. Oil Palm Conf. Nusa Dua, Bali. September $23-251998$ Indonesia.

Toruan-Mathius, N., N. Haris, T. Hutabarat dan G. Ginting. 1998. Analisis SDS-PAGE, IEF Protein dan RAPD pada Daun dan Buah Tanaman Kelapa Sawit Abnormal. Laporan Intern Unit Penelitian Bioteknologi Perkebunan. 10 p. 